Vol. 9 (2000): 253-257.

Research Note

\title{
Influence of changes in crop cultivation areas on pollen contents of honey
}

Anna-Liisa Varis

Department of Applied Zoology, PO Box 27, FIN-00014 University of Helsinki, Finland

\begin{abstract}
Pollen counts were done on honey collected by a Finnish honey corporation in late summer 1997 from the entire beekeeping area of Finland. The most common pollen type was Brassicaceae pollen, which was represented by $60 \%$ of the grains counted. It was followed by Salix spp. (10\%), Trifolium repens + T. hybridum (10\%) and T. pratense + T. medium (6.5\%) species. Pollen grains of Phacelia spp, Filipendula ulmaria, Apiaceae, Sorbus aucuparia, Malus domestica, and Rubus idaeus were also numerous. These pollen types constituted $96 \%$ of all the pollen examined.

These results and those of the earlier pollen counts in Finland were compared with the cultivation areas of the most important nectariferous crops. In the 1930s white clover was the most important honey source in Finland and its pollen was very dominant in honey. Since the 1950s oilseed crops have been grown in increasing rates and pure timothy-meadow fescue pastures and hay stands with heavy N applications have decreased the share of Trifolium species. The proportion of Brassicaceae pollen has continuously increased with the increase of the growing area of turnip rape Brassica rapa ssp. oleifera and rape, B. napus ssp. oleifera. At the same time the proportion of $T$. repens $+T$. hybridum pollen has decreased so that their mutual relationships are now reversed compared to the beginning of the 1960s. Changes in land use were thus very clearly to be seen in the pollen content of honey.
\end{abstract}

Key words: pollen analysis, land use, agricultural crops, Finland

\section{Introduction}

Pollen analytical studies have mainly been used to provide some idea of the geographical origin of honey and forage crops of bees and they have also been used to describe historical changes in the vegetation of the landscape (e.g. Hall 1997).
In the latter case pollen grains have been taken from peat or mud sediments.

Several studies of the pollen content of Finnish honey have been done during the last few decades. Martimo (1945) analysed 21 honey samples dating from the year 1937 and discussed their botanical origin. Aario (1961) studied 85 honeys in order to describe the regional condi- 
Varis, A.-L. Changes in crop cultivation areas and pollen contents of honey

tions of beekeeping. Purokoski and Forsius (unpublished) analysed 120 samples in 1962-1963, their main interest being their chemical composition. In 1977 and 1978 Varis et al. (1982) studied 160 samples to describe the average pollen spectrum of Finnish honey and to analyse the most important factors responsible for its variation.

During the last 60 years great changes have taken place in the agricultural practices and in the acreages of crops. Because of this the supply of honeybee forage plants has also dramatically changed. Most of all, the cultivation of oilseed crops has increased and the growing area of clovers has decreased. The purpose of this paper was to describe changes in agriculture during the last six decades through pollen analysis.

\section{Material and methods}

Pollen counts were made from honey samples taken from the containers of a Finnish corporation (Oy Hunajayhtymä $\mathrm{Ab}$ ) in the autumn of 1997. The corporation purchased honey from individual beekeepers throughout the entire beekeeping area in Finland at the end of the season. When one container was full, the next one was started. There were five containers, each with a capacity of 50,000 litres.

Before sampling the honey was stirred by means of electrically operated steel mixers. Two samples of 300 grams were taken from each container in glass jars at the end of September. The samples were thoroughly mixed and two subsamples of $10 \mathrm{~g}$ were taken from each sample for pollen analysis. Pollen counts were performed as described in Varis et al. (1982). The results of these and those of the earlier pollen counts in Finland were compared with the cultivation area of the main nectariferous crops (Central Statistical Office of Finland 1962, 1981).

\section{Results and discussion}

A total of 30 pollen types were identified either on the species or generic levels, and two were identified at the family level. The means and standard deviations of the pollen types representing cultivated plants are given in Table 1 . These pollens represented $81 \%$ of the pollen counted. The most common pollen type was Brassicaceae pollen, which represented $60 \%$ of the grains counted, followed by Trifolium species (16\%). Of the other pollen types Salix species (10\%) were the most numerous, followed by Filipendula ulmaria (2\%), Apiaceae species (2\%) and Sorbus aucuparia (1\%). Pollens of Brassicaceae, Trifolium repens $+T$. hybridum, T. pratense + T. medium and Salix spp. were present in all the samples.

Comparison of these results and those of the earlier pollen counts with the cultivation area of the main nectariferous crop are given in Fig. 1.

In 1937 Brassica oilseed crops were not grown in Finland, and Brassicaceae pollen was not found in honey. Then. by far the most common pollen type was Trifolium repens pollen. It was represented in all samples, and its percentage in half of the samples was as much as 85$100 \%$ (Martimo 1945). White clover was grown especially in pastures, often together with other clovers. Later, its proportion diminished. Since the 1950s oilseed crops have been grown in increasing rates.

Table 1. Counts of pollen types representing agricultural and horticultural crops $(\mathrm{N}=20)$.

\begin{tabular}{lrc}
\hline Plant species & Mean & $\begin{array}{c}\text { Standard } \\
\text { deviation }\end{array}$ \\
\hline Brassicaceae & 192.5 & 54.5 \\
Trifolium repens + T. hybridum & 31.6 & 23.2 \\
Trifolium pratense + T. medium & 20.7 & 6.3 \\
Phacelia spp. & 6.8 & 6.5 \\
Malus domestica & 3.6 & 3.9 \\
Rubus idaeus & 3.2 & 3.0 \\
Fragaria spp. & 0.2 & 0.6 \\
\hline
\end{tabular}




\section{AGRICULTURAL AND FOOD SCIENCE IN FINLAND}

Vol. 9 (2000): 253-257.

Fig. 1. Average proportion of Brassicaceae pollen in honey samples and the growing area of Brassica oilseed crops (Central Statistical Office in Finland 1962, 1981, Maa- ja metsätalousministeriön Tietopalvelukeskus 1998). Observations from 1937 by Martimo (1945), from 1960 by Aario (1961), from 1962 and 1963 by Purokoski and Forsius (unpublished), from 1977 and 1978 by Varis et al. (1982), and from 1997 (this study).

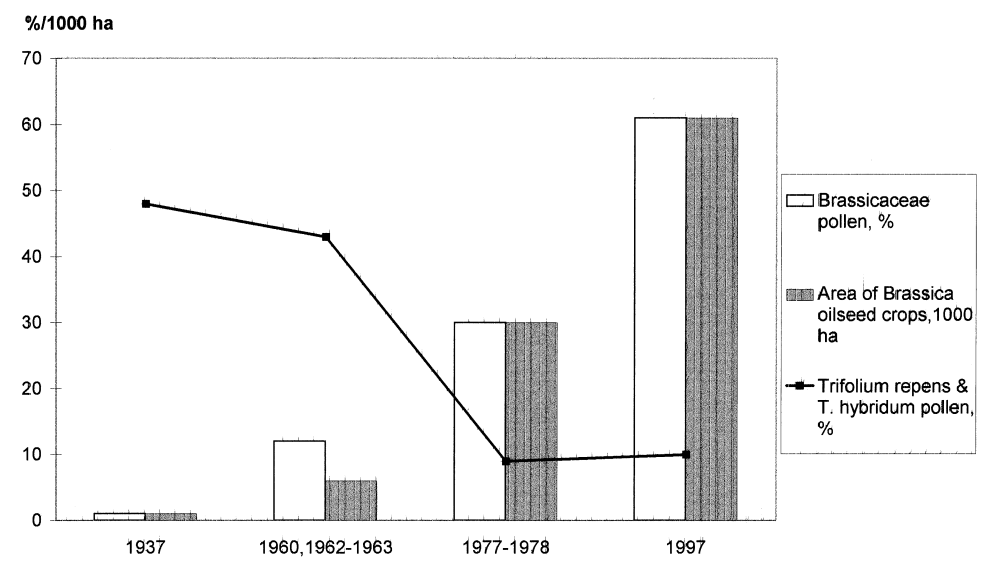

In the beginning of the 1960s the proportion of $T$. repens $+T$. hybridum pollen was approximately $42 \%$ of total pollen (Aario 1961, Purokoski and Forsius (unpublished)). In Finland $T$. hybridum has been the most important forage legume after red clover and its seeds were mainly taken from mixed clover-timothy stands (Valle 1960). About 6,000 ha of oilseed crops were under cultivation (Central Statistical Office of Finland 1962) and the proportion of Brassicaceae pollen averaged $12 \%$.

At the end of the 1970s the growing area of oilseed crops had increased up to 30,000 hectares (Central Statistical Office of Finland 1981) due to a new subsidy policy, and the percentages of Brassicaceae pollen counts were about 30 (Varis et al. 1982). The proportion of T. repens + T. hybridum pollen was less than $10 \%$. Changing over from mixed clover-grass stands to pure graminaceous stands with heavy $\mathrm{N}$ application had diminished the role of clover in pastures and hay fields. The cutting of forage crops is also done earlier, generally before flowering. The decrease in cattle farming has also reduced the pasture areas.

In 1997 oilseed crops were grown in 61,000 hectares (Maa- ja metsätalousministeriön tietopalvelukeskus 1998). The percentage of Brassicaceae pollen was $60 \%$ and that of T. repens + T. hybridum $10 \%$ (present study).

There are many wild Brassicaceae plants growing in the fields and meadows but compared with cultivated crucifers their role seems to be marginal. The amount of land used to cultivate other honeybee forage plants (Table 1) is small and local, and the proportions of their pollen varied according to the samples. No comparison could be made of any changes that might have occurred to them during the study period. Of these plants Phacelia spp. is cultivated by some beekeepers in the neighbourhood of beehives and in set-aside fields.

In spite of the decrease of the seed production areas of red clover (Table 2, information given in a letter from the Ministry of Agriculture and Forestry) the role of its pollen was higher in the 1970s and 1990s than in the 1960s. In the 1930s there were no special seed production

Table 2. The red clover seed production areas (Information given in a letter from the Ministry of Agriculture and Forestry) and the roles of Trifolium pratense $+T$. medium pollen in the study years.

\begin{tabular}{lcc}
\hline Year & Seed production area & Pollen $\%$ \\
\hline 1937 & - & - \\
$1960,1962-1963$ & 6717 & $1-2$ \\
$1977-1978$ & 2950 & 5.4 \\
1997 & no statistics available ${ }^{*)}$ & 6.5 \\
\hline
\end{tabular}

*) but considerable smaller than in 1977-1978, the harvested area was only 706 ha. 
Varis, A.-L. Changes in crop cultivation areas and pollen contents of honey

areas but the seeds were produced together with timothy and T. hybridum as has been done to some extent later.

The flowers of red clover have a long corolla which restricts the ability of honeybees to penetrate them. In the past, by far the most common bee race in Finland was the Black bee (Apis mellifera mellifera) but since the 1970s the role of the Italian bee (Apis mellifera ligustica) has increased so that it comprised in 1988-1989 about $70 \%$ of the bee colonies, the role of the Black bee being 5-10\% (Peltotalo 1990). The tongue of the Italian bee is considerably longer, being 6.3-6.6 $\mathrm{mm}$ than that of the Black bee, which is $5.7-6.4 \mathrm{~mm}$ long (Ruttner 1975). The number of bee colonies has also increased from 15,000 in the 1930s (Tuomainen 1931) to 45,000 in the 1990s (Peltotalo 1990). The colonies are now also more often moved to the flowering plants than earlier. These facts may partly explain the increased role of red-clover pollen in the later counts.

Because the containers were filled randomly in the order of the arrival of honey batches from different regions of the country, there were differences between the samples, but on the whole a good overview was obtained of the present pollen composition of Finnish honey. Although the pollen spectrum alone is not a reliable index of the botanical origin of honey, the changes in pollen spectrum very well reflected the changes in the acreages of main honeybee forage crops.

Hjelle (1999) found that the pollen assemblages of surface moss polsters reflected the local vegetation. Gradients were found in the pollen assemblages relating to land-use practices as well as geographical regions. According to Kenyon and Rutherfurd (1999) analysis of pollen in floodplain sediments provided a technique for identifying major historical changes in vegetation.

The present study shows that changes in agricultural policy which have changed the agricultural systems and land use are to be seen in the pollen content of honey.

Acknowledgements. I am grateful to Mrs Silja Mäkelä for her technical assistance and to Mr Erkki Ruohonen for supplying the honey samples.

\section{References}

Aario, R. 1961. Mehiläishoidon levinneisyys ja sen maataloudelliset edellytykset Suomessa. Mimeogr. 70 p. (Available at Department of Geography, University of Helsinki, Finland).

Central Statistical Office of Finland 1962. Statistical Yearbook of Finland 1962. 477 p.

- 1981. Statistical Yearbook of Finland 1981. 517 p.

Hall, V. 1997. The development of the landscape of Ireland over the last two thousand years; fresh evidence from historical and pollen analytical studies. Chronion 1, 1: 1-22.

Hjelle, K.L. 1999. Modern pollen assemblages from mown and grazed vegetation types in western Norway. Review of Palaeobotany \& Palynology 107: 55-81.

Kenyon, C. \& Rutherfurd, I.D. 1999. Preliminary evidence for pollen as an indicator of recent floodplain accumulation rates and vegetation changes: The BarmahMillewa Forest, SE Australia. Environmental Management 24: 359-367.
Maa- ja metsätalousministeriön Tietopalvelukeskus 1998. Lopulliset satotulokset vuosina 1997 ja 1998. 1 p.

Martimo, M. 1945. Suomalaisen hunajan ominaisuuksista ja alkuperästä. Maataloustieteellinen Aikakauskirja 17: 157-169.

Peltotalo, P. 1990. Selvitys mehiläistarhauksesta ja hunajan markkinoinnista Suomessa osa II. Mehiläinen 6:165-171.

Ruttner, F. 1975. Races of bees. In: The Hive and the Honey Bee. Dadant \& Sons, Hamilton, IL. p. 19-38.

Tuomainen, L. 1931. Lyhyt mehiläishoidon opas. Porvoo. $86 \mathrm{p}$.

Valle, O. 1960. Alsikeapilan siementuotantomahdollisuuksista Suomessa. Summary: Possibilities of alsike clover seed production in Finland. Maatalous ja Koetoiminta 14: 118-127.

Varis, A.-L., Helenius, J. \& Koivulehto, K. 1982. Pollen spectrum of Finnish honey. Journal of the Scientific Agricultural Society of Finland 54: 403-420. 
Vol. 9 (2000): 253-257.

\title{
SELOSTUS
}

\section{Viljelyalojen muutosten vaikutus hunajan siitepölysisältöön}

\author{
Anna-Liisa Varis \\ Helsingin yliopisto
}

Syksyllä 1997 otettiin hunajanäytteet viidestä Oy Hunajayhtymä Ab:n 50000 litran vetoisesta säiliöstä, joihin oli vastaanotettu hunajaa mehiläishoitajilta ympäri maata. Näytteistä tehtiin siitepölymääritykset ja tuloksia verrattiin aikaisemmin Suomessa tehtyjen siitepölymääritysten tuloksiin ja tärkeimpien mehiläiskasvien viljelypinta-aloissa tapahtuneisiin muutoksiin.

Yleisin siitepölylaji oli ristikukkaiskasvien siitepöly, jonka osuus oli $60 \%$ kaikista lasketuista siitepölyistä. Seuraavina olivat pajut $(10 \%)$, valko- ja alsikeapila (10\%) sekä puna- ja metsäapila, 6,5\%. Hunajakukan, mesiangervon ja muiden sarjakukkaisten, pihlajan, omenan ja vatun siitepölyjä esiintyi myöskin melko lukuisasti. Yhteensä näiden siitepölylajien osuus oli yli $96 \%$ koko aineistosta.
Varhaisimmat hunajan siitepölymääritykset maassamme ovat 1930-luvun lopulta. Valkoapila oli silloin tärkein hunajakasvi ja sen siitepöly hunajassa oli dominoiva. 1950-luvulta lähtien ristikukkaisten öljykasvien viljely yleistyi. Samanaikaisesti nurmet muuttuivat heinävaltaisiksi ja apilan osuus väheni. Rypsin ja rapsin viljelyn lisääntyessä ristikukkaissiitepölyn osuus hunajassa on jatkuvasti lisääntynyt ja apiloiden vähentynyt. Suomalaisen hunajan siitepölykoostumus on tärkeimpien lajien osalta näin muuttunut aikaisempaan verrattuna täysin päinvastaiseksi. Vaikka siitepölysisältö yksin ei ole luotettava hunajan botaanisen alkuperän mittari, tärkeimpien mehiläiskasvien viljelyaloissa tapahtuneet muutokset heijastuivat erittäin selvästi hunajaan. 